\title{
Freeze-Etching Observation on the Development of Intercellular Junctions of the Duodenal Epithelial Cells in the Chick Embryo*
}

\author{
Hisao Окамото and Kazunori IshimuRA
}

Received January 23, 1978

Summary. Development of intercellular junctions in duodenal epithelium in the chick embryo was studied by electron microscopy using the thin-section and freeze-fracture techniques.

Incomplete tight junctions are already seen in 6 and 7 day old embryos at the apical portion of the lateral plasma membrane, and consist of 1-7 strands, their mean depth measuring $0.2 \mu \mathrm{m}$. This corresponds to a "very leaky type" (CLAUDE and GoodENOUGH) of tight junction. Ridges on the $P F$ are discontinuous and rarely cross or link. The tight junctions extend basally at the place where more than three epithelial cells are in contact. On the lateral plasma membrane, particle-aggregates suggesting primitive gap junctions are already recognized. Some are dense aggregations of 3-5 membrane-particles with a halo free of the particles and others are rather loose aggregations of 5-10 particles with an indistinct halo.

In 9 day old embryos, the ridges of the tight junction become more discontinuous, although the frequency of the linkage of the neighboring ridges increases. The compartments bounded by the tight junctional strands are angular. These strands become continuous and the facets surrounded by them are roundish in $\mathbf{1 2}$ day old embryos.

The presumptive immature gap junctions show a characteristic polygonal pattern in 9 day old embryos and gradually increase in size.

Mature tight junctions and typical gap junctions of $0.3-0.4 \mu \mathrm{m}$ diameter are seen after 18 days of incubation. The strands number 6-8 and the depth of the tight junction measures about $0.4 \mu \mathrm{m}$ in 18 day old embryos.

In the chick embryo duodenal epithelium, the tight and gap junctions develop independently from each other without any direct interaction between them.

Intercellular junctions such as tight as well as gap junctions develop from differentiation of the cell membrane and each junction has been considered to have its own function (StAEhelin, 1974). Of these junctions, the tight junction and gap junction are well known to show their characteristic figures in freeze-fracture images.

The tight junction (zonula occludens), which was originally described as the outermost element of the junctional complex by FARQUHAR and PALADE (1963), is usually recognized between neighboring cells as a sequence of pentalaminar fusions in thin sections. In freeze-replica, this junction has been shown to be a network of ridges on the $\mathrm{PF}$ with complementary furrows or grooves on the $\mathrm{EF}$ of the cell membranes (Kreutziger, 1968; Staehelin et al., 1969; Chalcroft and Bullivant, 1970; Goodenough and Revel, 1970; Friend and Gilula, 1972). It is believed that the tight junction serves as the permeability barrier (FARQUhar and PALAdE, 1963; REESE and Karnovsky, 1967; Goodenough and Revel, 1970), and its sealing effect was shown to

* This paper was supported by a grant from the Japan Ministry of Education. 
be correlated with the depth and number of strands of this junction by CLAUDE and Goodenough (1973).

Gap junctions, which appear as pentalaminar or septilaminar membrane appositions with a $20-40 \AA$ gap in thin sections, are generally recognized to be the polygonally packed arrays of membrane particles on the PF with the complementary pits on the EF of the plasma membrane in a freeze-fracture image (KREUTZIGER, 1968; Chalcroft and Bullivant, 1970; McNutt and Weinstein, 1970; Friend and Gilula, 1972; Staehelin, 1974). It has been reported that the gap junction plays an important role in intercellular communication (PAPAs et al., 1971; Revel et al., 1971; GILuLA et al., 1972).

As to the formation of the tight and gap junctions, many reports have been published (Revel et al., 1973; Albertini and Anderson, 1974; Decker and Friend, 1974; Johnson et al., 1974; Montesano et al., 1975; Decker, 1976; Humbert et al., 1976; Dermietzel et al., 1977; Pannese et al., 1977). It is expected, however, that the different kinds of tissue or organ might show a different pattern of junction formation. Besides the above, another question arises whether or not there is a relationship between the tight junction and gap junction in the process of their development as several investigators have suggested (Montesano et al., 1975; NAGAno and Suzuki, 1976).

The present paper concerns the process of the tight junction and gap junction formation in the duodenal epithelium of the chick embryo using thin-sections and freeze-fracture preparations.

\section{Materials and Methods}

The duodenum of White Leghorn chick embryos at 6, 7, 9, 12, 13, 15, 18, 21 days of incubation were used for this study.

Freeze-fracture: Duodenal tissues excised were fixed for 24 hrs in $2.5 \%$ glutaraldehyde buffered at $\mathrm{pH} 7.4$ with Millonig's phosphate. After fixation, tissue blocks were soaked in 30-40\% glycerol solution for $4-12$ hrs and rapidly frozen in freon 22 cooled with liquid nitrogen. Replicas were made in a JEM EE-FED type freezeetching apparatus and examined in a Hitachi HU-11D type electron microscope.

Thin section: Some of the duodenal tissues were fixed for $2 \mathrm{hrs}$ in $2.5 \%$ glutaraldehyde buffered at $\mathrm{pH} 7.4$ with Millonig's phosphate postfixed in $1 \% \mathrm{OsO}_{4}$, then dehydrated in graded concentrations of alcohol and embedded in Epon epoxy resin. Some other tissues were fixed in a $2.5 \%$ glutaraldehyde solution containing $2 \%$ tannic acid for 12-16 hrs, postfixed in $1 \% \mathrm{OsO}_{4}$ and stained en bloc with uranyl acetate. After dehydration in graded concentrations of alcohol, samples were embedded in Epon epoxy resin.

Sections were cut with a Porter-Blum ultramicrotome, stained with Millonig's lead acetate and examined in a Hitachi HU-11D type electron microscope.

\section{Observations}

\section{Tight junction}

Six to 7 days of incubation

Junctional complexes are already noticed between the duodenal epithelial cells 
of the 6-7 day old chick embryo in thin sections. On these days, the tight junctions are recognized as 2 or 3 punctate fusions of the outer leaflets of the lateral plasma membranes of the epithelial cells (Fig. 1, 2).

With the freeze-fracture technique, detailed structures become clearer and some specific arrangements of membrane-particles are recognized on the PF of the lateral plasma membrane.

The tight junctions which are observed at the apical portion of the lateral plasma membrane consist of 1-7 strands running parallel to the apical plasma membrane and their depth measures $0.21 \pm 0.12 \mu \mathrm{m}$ in a 6 day old embryo (Fig. 3, 4). Ridges on the PF are usually discontinuous and some parts often consist of linear arrays of the membrane-particles (Fig. 3). Neighboring ridges rarely cross each other in their course, and an optional course can be pursued through the cracks of the ridges from the luminal portion to the basal side. The tight junctions extend basally at the place where more than three cells are in contact.

Nine, 12, 15 days of incubation

With the development of the embryo, the strands of the tight junctions increase in number. They number $5.3 \pm 1.1$ (range $4-7$ ) and their depth measures $0.31 \pm 0.09 \mu \mathrm{m}$

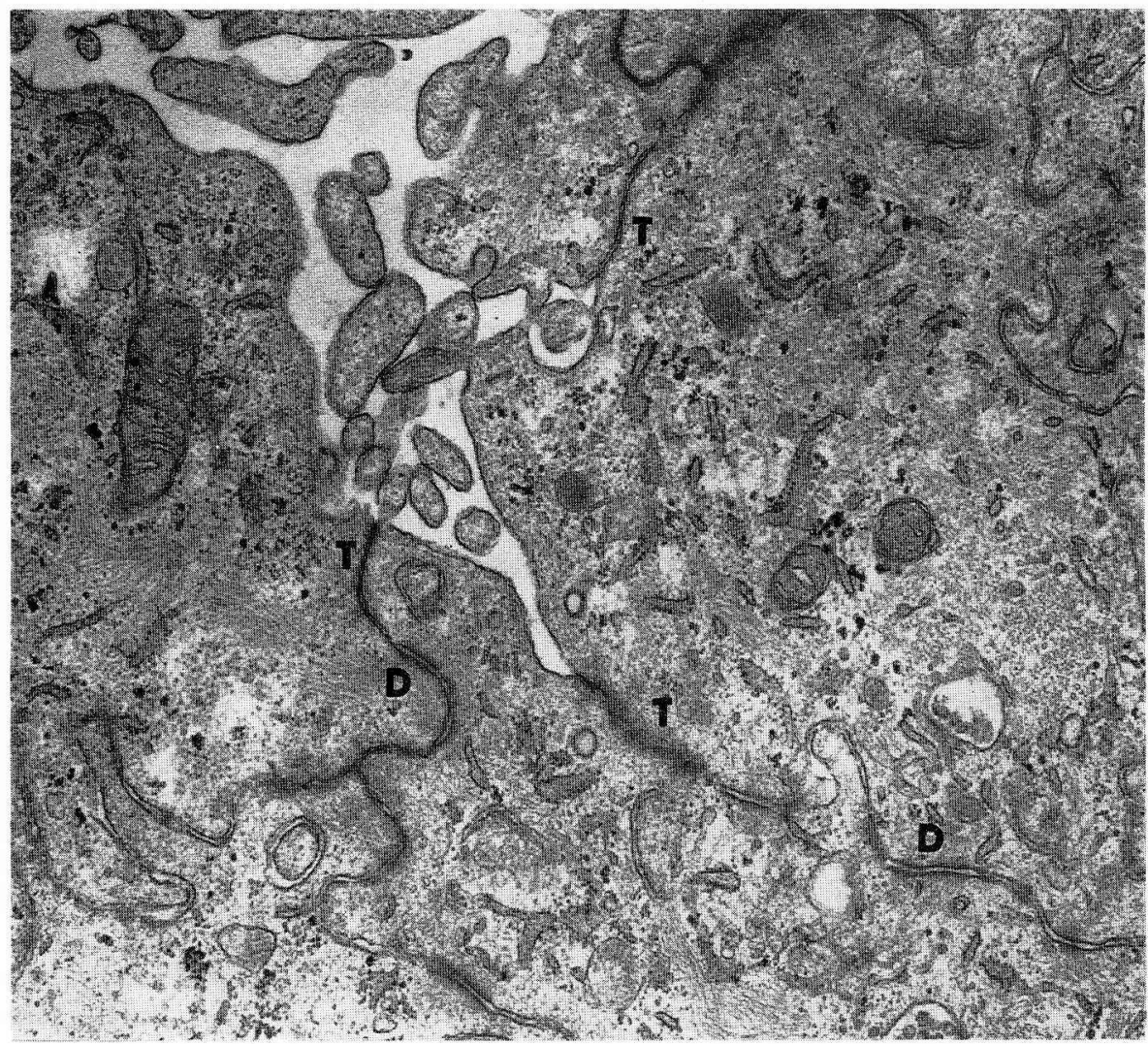

Fig. 1. A part of duodenal epithelium of a 6 day old chick embryo. Notice tight junctions $(T)$ and desmosomes $(D) . \quad \times 21,000$ 


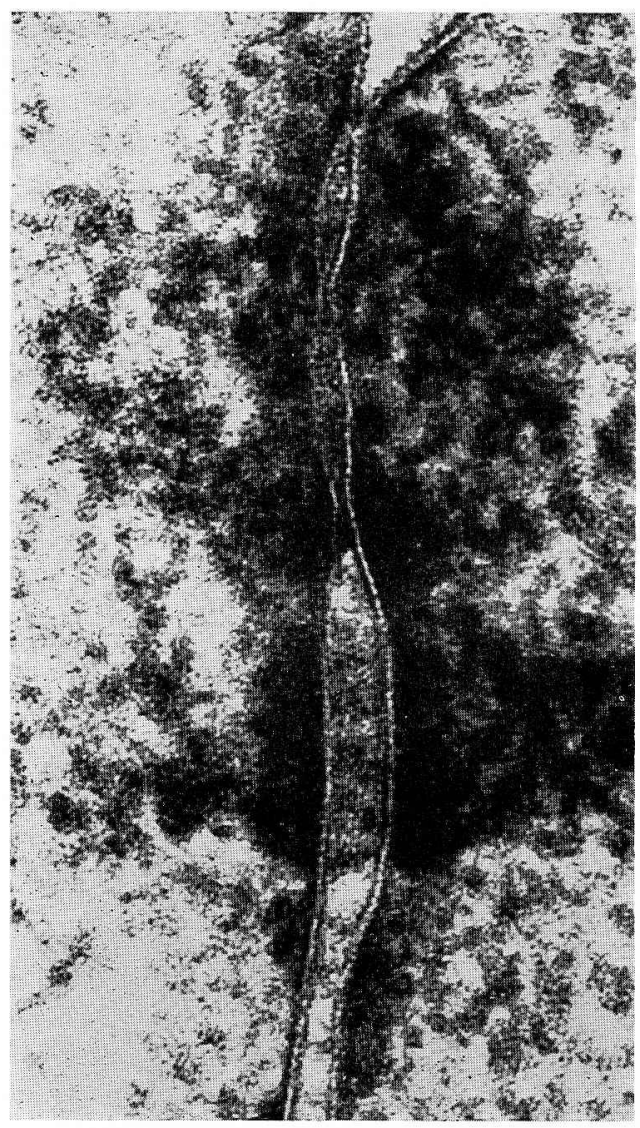

Fig. 2. Junctional complex between two duodenal epithelial cells of a 6 day old chick embryo (tannic acid fixation). In the tight junction, the outer leaflets of the plasma membrane are fused at only 3 points. $\times 176,000$ in the 12 day old embryo. The frequency of the linkage of the neighboring ridges also increases.

In the 9 day old embryo, the facets made up of the tight junctional strands are angular in appearance (Fig. 5). The ridges are partly formed by the discrete membrane particles and are more discontinuous than in younger embryos. On the EF, however, only a few particles are solitarily stuck on the furrows. In the 12 day old embryo, the connections of ridges on the PF increase in number and the facets surrounded by the strands become roundish (Fig. 6). The contour of the ridges becomes smooth in the embryo older than 12 days of incubation (Fig. 6, 7).

Tight junctions of the duodenal epithelium in the 15 day old embryo are very hard to distinguish from those of the older ones in thin sections (Fig. 8).

\section{Eighteen and 21 days of incubation}

At 18 days of incubation, the strands forming the tight junctions number $7.2 \pm 2.3$ (range $4-11$ ) and the depth of the junction measure 0.38 $\pm 0.12 \mu \mathrm{m}$; while the course of the strands is smooth and wavy (Fig. 9, 10). Tight junctions of the 18 day old chick embryo are difficult to distinguish from those of the older ones in freeze-fracture images.

\section{Gap junction}

At 6 to 7 days of incubation, no typical gap junctions are detected but two types of membrane-particle aggregations are recognized (Fig. 3, 11). One is a densely packed aggregation consisting of 3-5 membrane-particles seen beneath the tight junction on the PF (Fig. 3). This type of aggregation is surrounded by a particle-free area, the so called halo. The other type is a somewhat loose aggregation of 5-10 particles with an indistinct halo and is scattered over the PF of the lateral plasma membrane (Fig. 11). Both might be a primitive gap junction. No particle-aggregates are enclosed by the ridges of the tight junction.

During 9-15 days of incubation, two types of particle-aggregates are observed on the PF. One is a somewhat loose aggregate of 5-10 particles (Fig. 12), and the other is a polygonal aggregate of 20-30 membrane-particles (Fig. 12). Both of them have a distinct halo. 

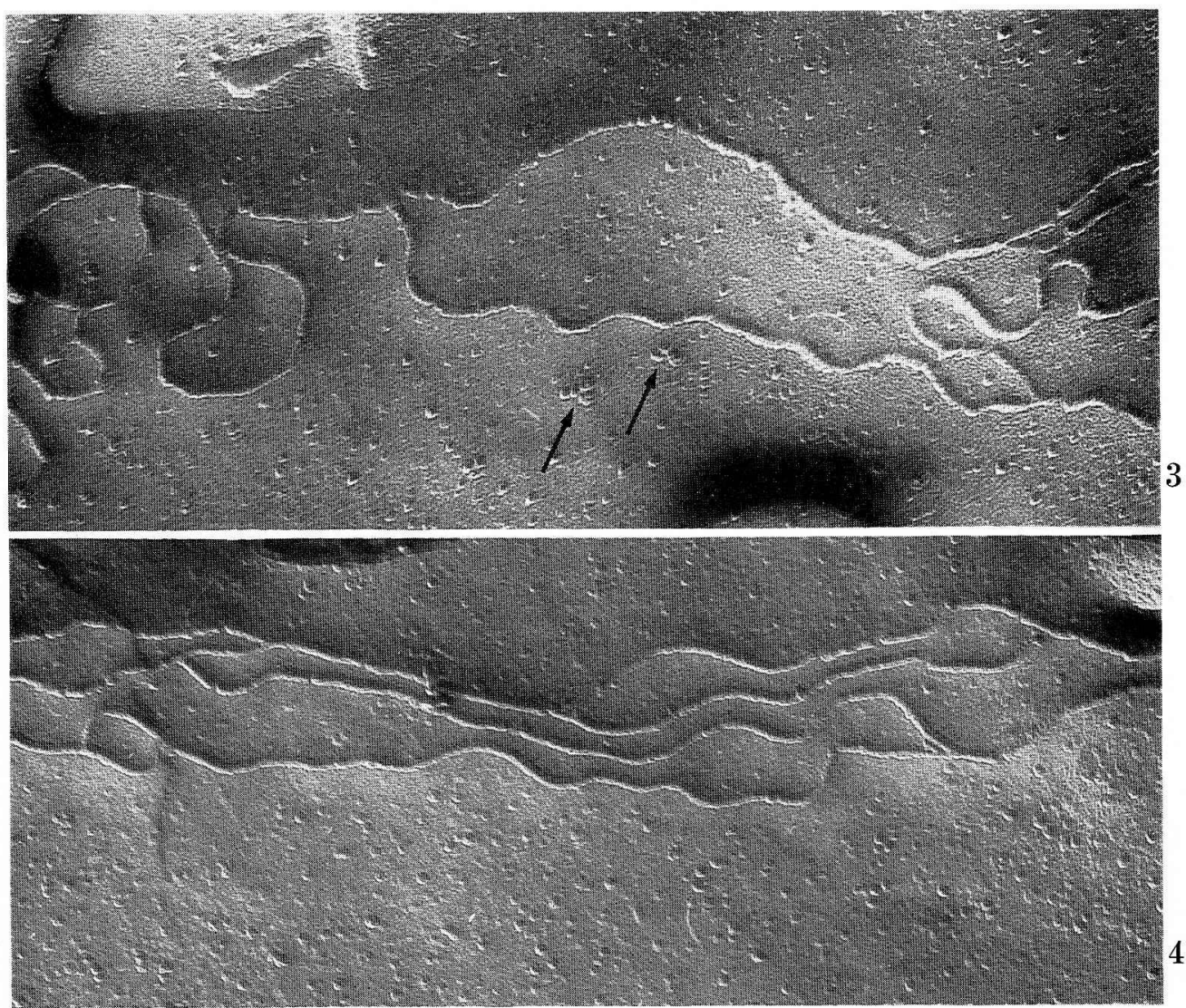

Fig. 3 and 4. Freeze-etching image of tight junctions in the duodenal epithelium (PF) of a 6 day old chick embryo. Strands making the tight junction are small in number, and are discontinuous in some parts. Notice small particle-aggregates (arrows).

Fig. 3. $\times 88,000$, Fig. 4. $\times 89,000$

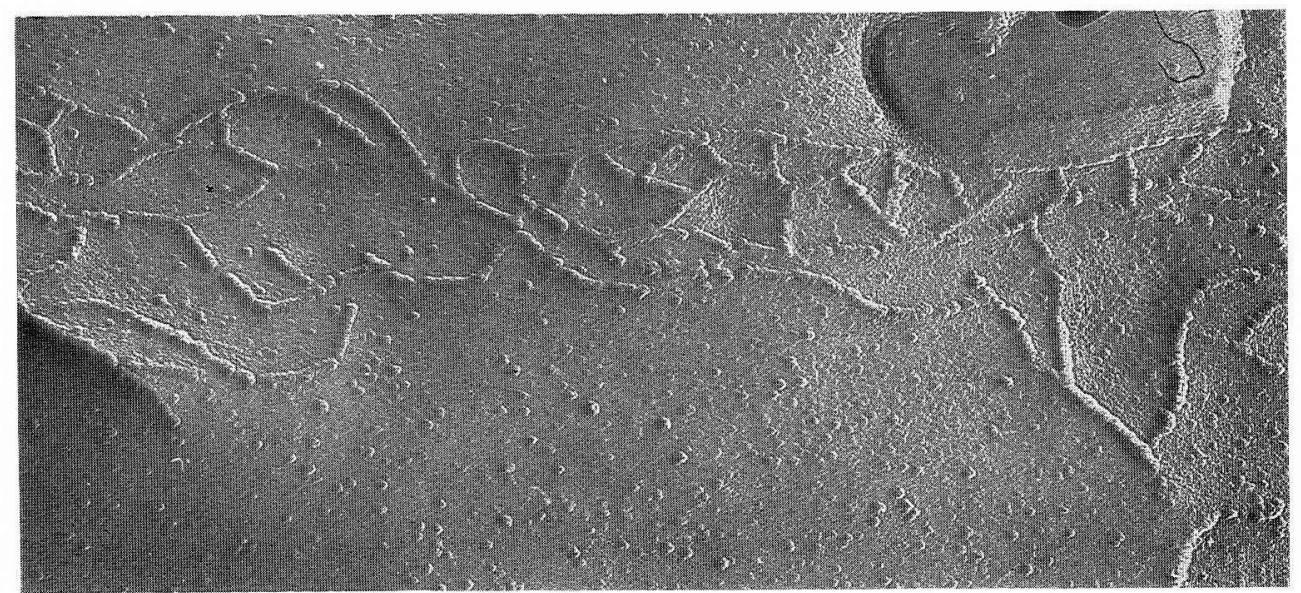

Fig. 5. Freeze-etching image of tight junction of the duodenal epithelium (PF) in a 9 day old chick embryo. Strands are discontinuous. $\times 77,000$ 
Typical gap junctions $0.3-0.4 \mu \mathrm{m}$ in diameter are observed in 18-21 day old chick embryos and small $20 \AA$ central pits are noticed on their elementary membraneparticles (Fig. 14, 15). An irregular-shaped aggregation of 20-25 membrane particles surrounded by the halo is sometimes observed near the gap junction.

\section{Discussion}

\section{Formation of tight junction}

It is thought that the formation of the tight junction of the chick embryo duodenal epithelium proceeds as follows:
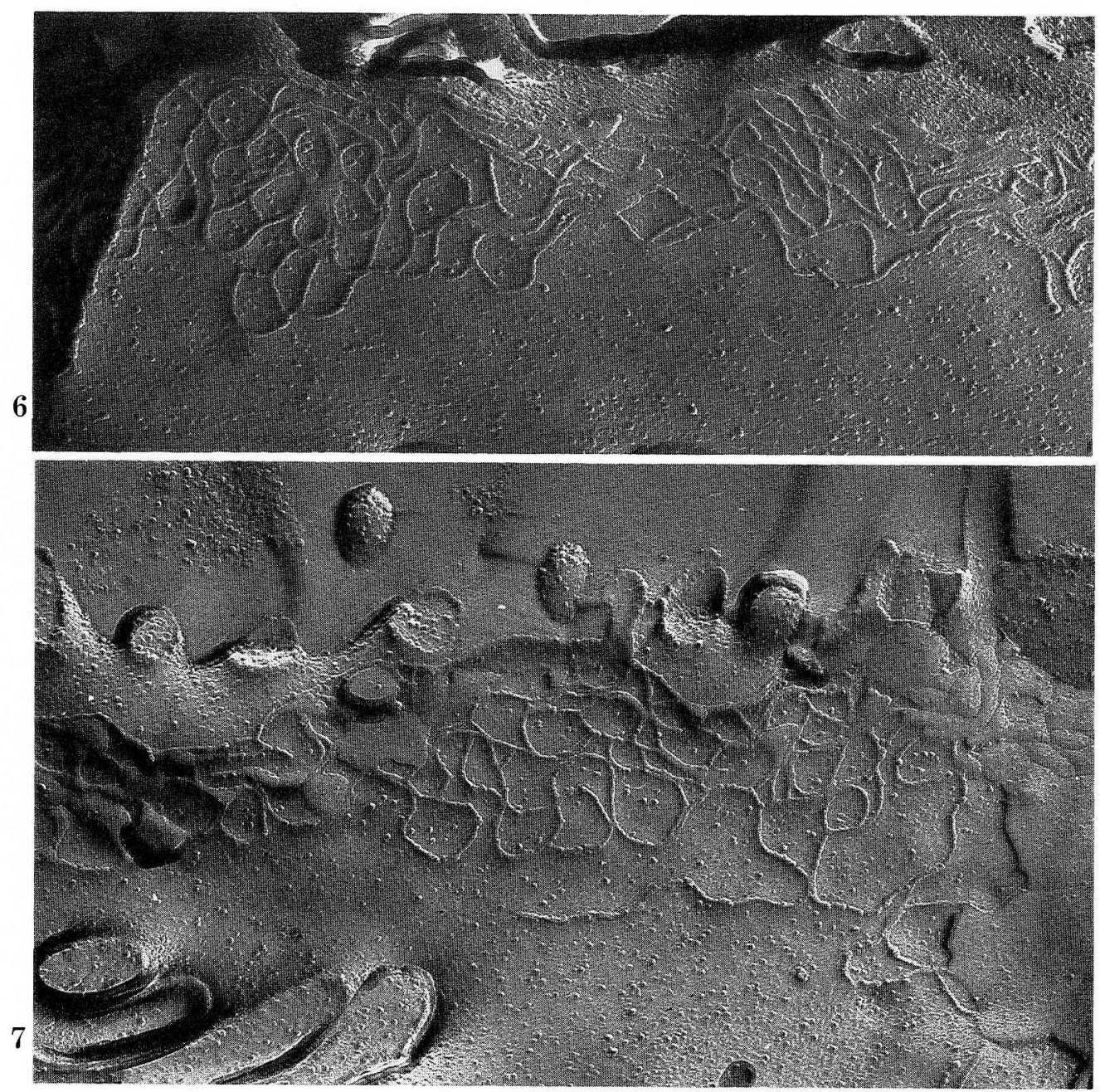

Fig. 6. and 7. Freeze-etching images of tight junction of the duodenal epithelium of a 12 day old embryo (Fig. 6), and a 15 day old embryo (Fig. 7). Strands are larger in number and continuous as compared with those of 6-9 day old embryos. Fig. 6. $\times 59,000$, Fig. 7. $\times 54,000$ 
1. A few discontinuous junctional strands running parallel to the luminal plasma membrane are formed at the apical portion of the lateral plasma membrane by the 6 th day of incubation. They rarely branch or cross with each other.

2. In the 9 day old embryo, the strands of this simple tight junction are cut into several short segments and the neighboring cut ends join. Therefore, these strands form angular facets and each former ridge becomes more discontinuous due to the deficit of the component.

3. During 9-12 days of incubation, the ridges become continuous with replenishment of the membrane-particles and their contour becomes smooth.

4. On and after 12 days of incubation, the strands come to take a smooth and wavy course. The number of the strands and the depth of the tight junction gradually increase. In the 18 day old embryo, the tight junction is morphologically completed.

Atypical tight junction, whose particles are predominantly located on the grooves of the EF instead of the ridges on the PF, were reported in the mouse Sertoli cells (NAGANO and Suzuki, 1976) and unidentified parts of the nephron of the human and rat kidney (Humbert et al., 1976). However, the increased discontinuities of the ridges observed in the 9 day old embryo are not due to the transposition of their components, because the number of membrane-particles stuck on the grooves of the EF is not enough to make up the deficit of the ridges on the PF.

It has been reported in several tissues

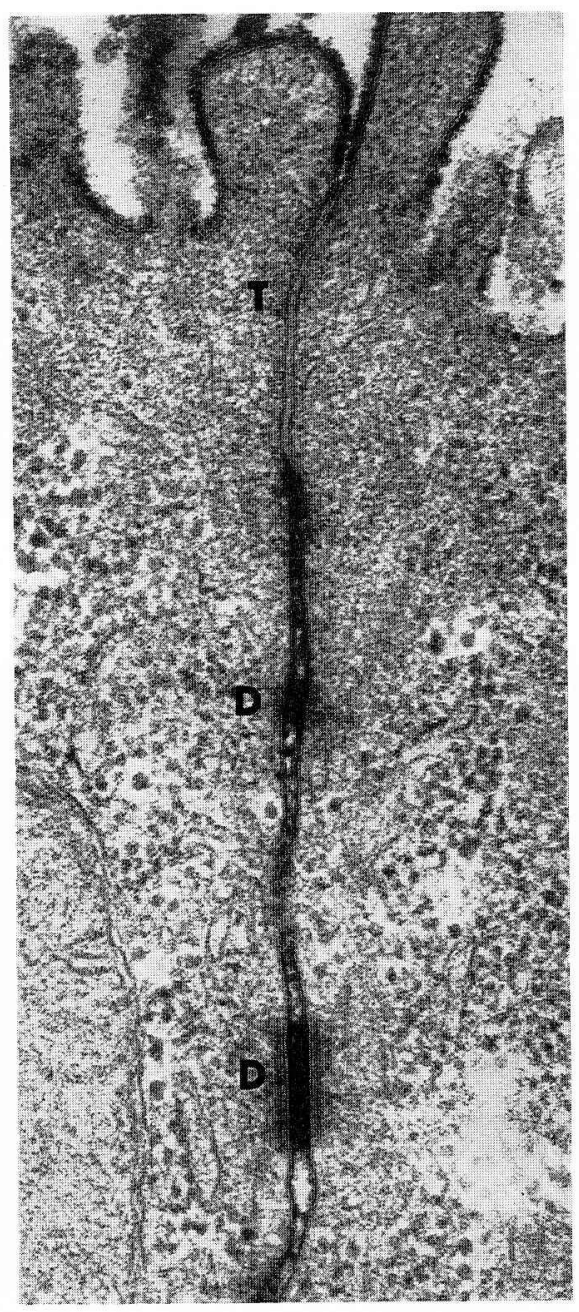

Fig. 8. Junctional complex between two duodenal epithelial cells of a 15 day-old chick embryo (tannic acid fixation). At a tight junction ( $T$ ), the intercellular space is completely sealed. $D$ desmosome. $\times 64,000$ that the formation of the tight junction is probably influenced by a gap junction or gap junction-like particle aggregation (Montesano et al., 1975; Nagano and SuzukI, 1976; Dermietzel et al., 1977). In the present study, however, neither gap junctions nor gap junction-like particle aggregations that are in contact with the tight junction were recognized. Therefore, it is unlikely that the gap junction plays an important role in formation of the tight junction as far as the duodenal epithelium of the chick embryo is concerned. Claude and Goodenough (1973) examined the tight junction of various epithelia and classified them into 5 types: very leaky, leaky, intermediate to tight and very tight. For example, the "leaky" tight junctions, such as 


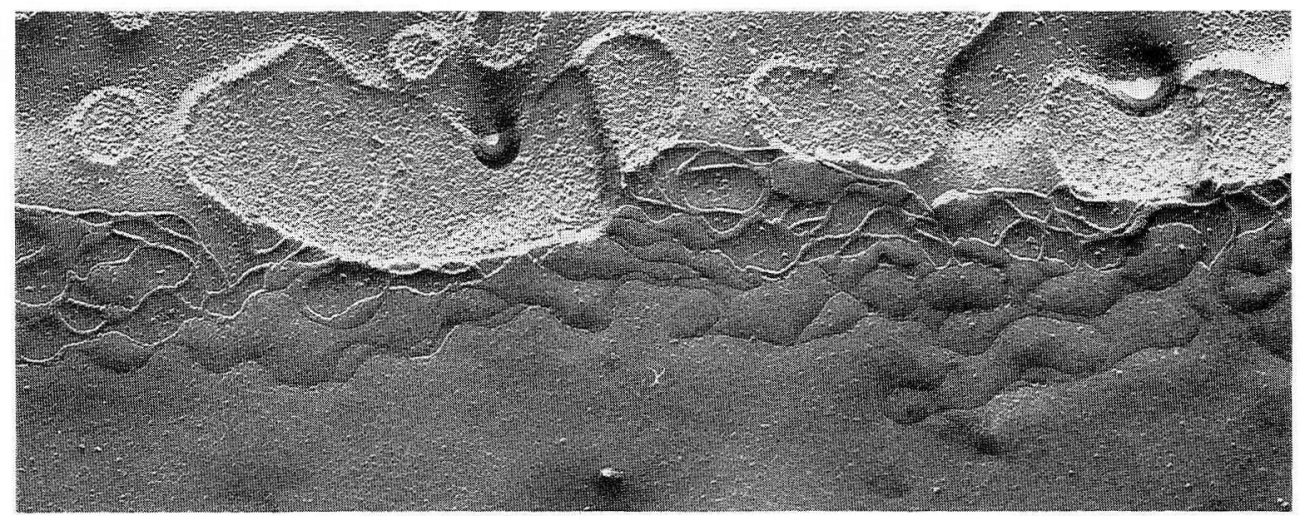

Fig. 9. Freeze-etching image of tight junction of the duodenal epithelium of an 18 day old embryo. $\times 55,000$

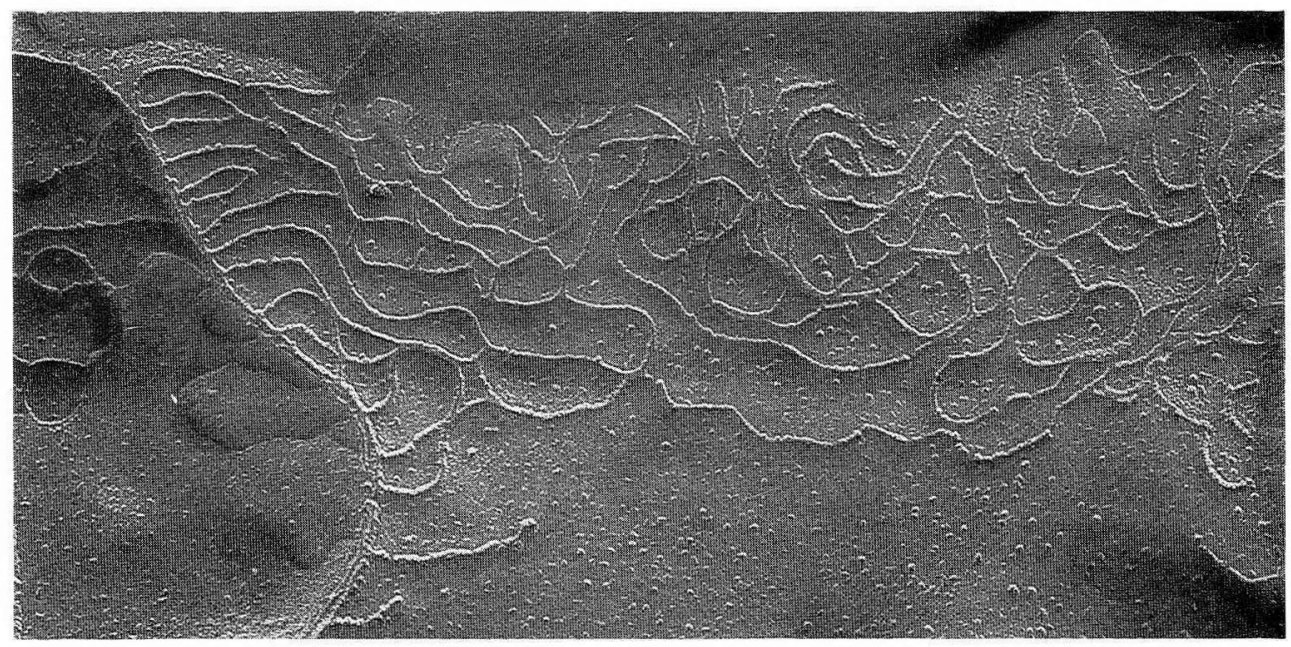

Fig. 10. Well developed tight junction in the duodenal epithelium of an 18 day old chick embryo. Numerous strands linked with one another are seen. $\times 64,000$

Table 1. Measurements of tight junctions of the duodenal epithelium in 6,12 and 18 day old chick embryos.

\begin{tabular}{c|cc|cc}
\hline $\begin{array}{c}\text { Age of embryo } \\
\text { (day) }\end{array}$ & \multicolumn{2}{|c|}{ Strands (number) } & \multicolumn{2}{c}{ Depth $(\mu \mathrm{m})$} \\
mean \pm S.D. & range & mean \pm S.D. & range \\
\hline 6 & $3.6 \pm 1.64$ & $1-7$ & $0.21 \pm 0.116$ & -0.41 \\
12 & $5.3 \pm 1.14$ & $4-7$ & $0.31 \pm 0.086$ & $0.16-0.41$ \\
18 & $7.2 \pm 2.33$ & $4-11$ & $0.38 \pm 0.124$ & $0.20-0.66$ \\
\hline
\end{tabular}

Measurements were made parallel to the luminal surface every $0.3 \mu \mathrm{m}$. 
those found in the proximal convoluted tubules of the Necturus, have 1-6 strands and measure $0.1-0.8 \mu \mathrm{m}$ in depth. In the present study, the tight junction of the duodenal epithelium is very leaky in type in the 6 day old embryo, intermediate in the 12 day

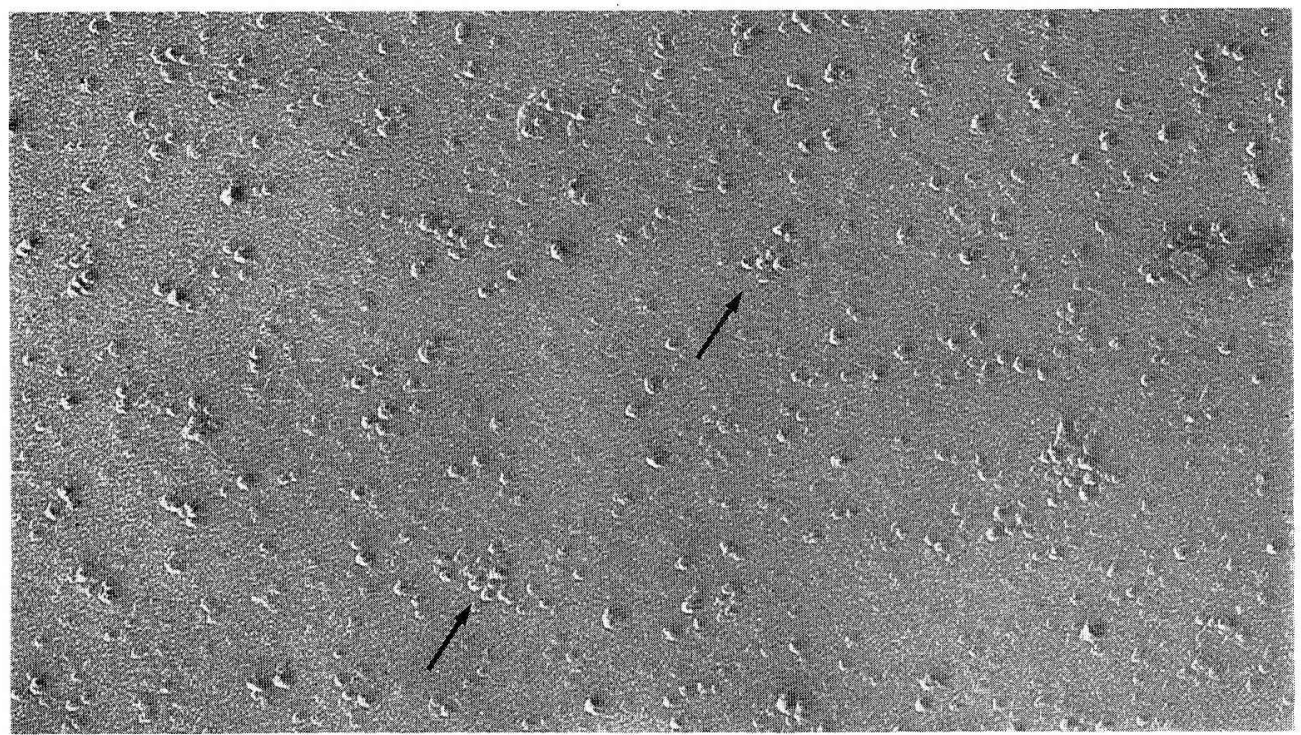

Fig. 11. Lateral plasma membrane (PF) of a duodenal epithelial cell in 6 day old chick embryo. Notice aggregates of membrane-particles (arrows). $\quad \times 119,000$

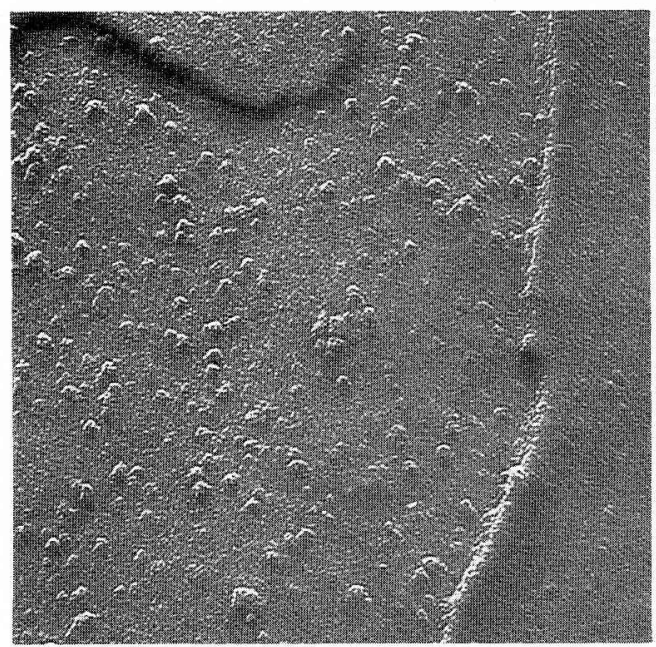

12

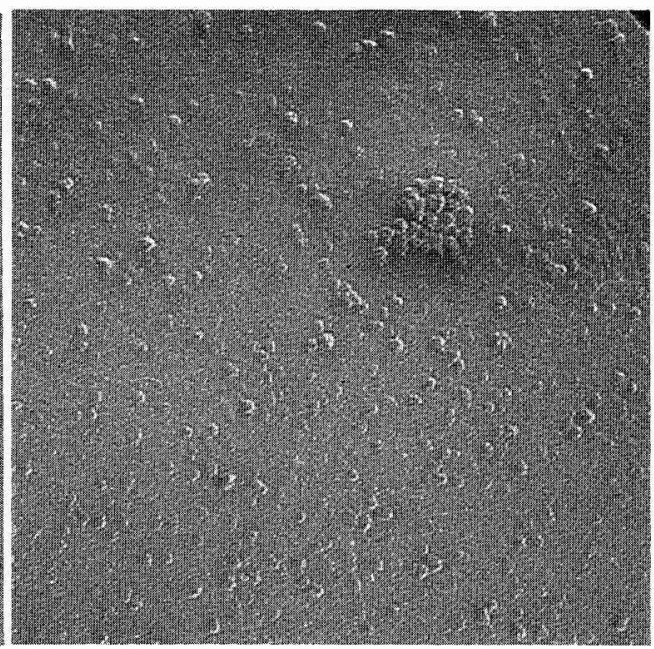

13

Fig. 12. Lateral plasma membrane (PF) of a duodenal epithelial cell in a 9 day old chick embryo. Notice particle aggregations surrounded by a halo free of membrane-particles. $\times 108,000$

Fig. 13. An immature gap junction in the duodenal epithelium (PF) of a 13 day old chick embryo. The gap junction is surrounded by a halo free of membrane-particles. $\quad \times 105,000$ 
old embryo, and intermediate to tight or very tight in the 18 day and older embryos (Table 1).

\section{Formation of gap junction}

Small particle-aggregations without a halo seen on the PF of the lateral plasma membrane in the 6 day old embryo likely represent the earliest stage of the formation of gap junctions. Similar particle-aggregations with a halo may be more developed gap junctions. These presumptive immature gap junctions have a characteristic polygonal pattern in the 9 day old embryo and gradually increase in size, and the typical gap junctions, $0.3-0.4 \mu \mathrm{m}$ in diameter, appear just before hatching. FujIsAwA et al. (1976) reported that the well developed gap junctions of the neural retina in the chick embryo disappear after 6 days of incubation, and similar phenomenon was ob-

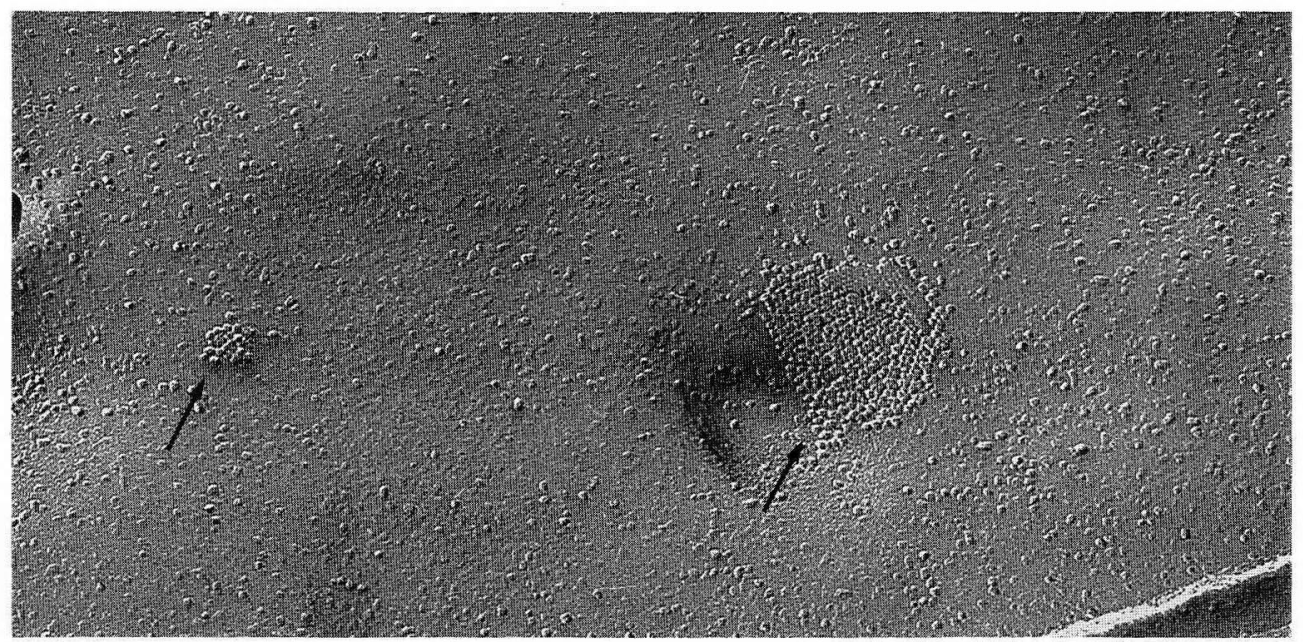

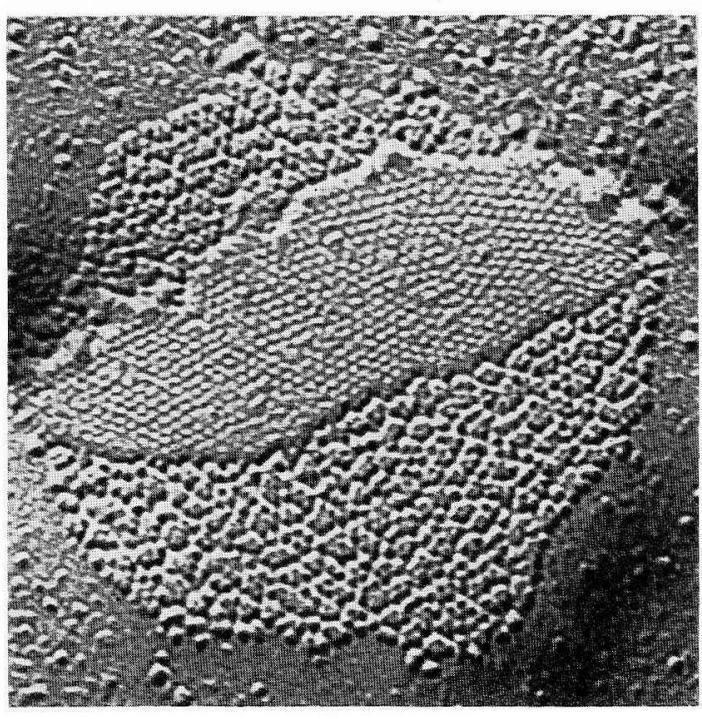

Fig. 14. Two gap junctions (arrows) in the duodenal epithelium of a 21 day old chick embryo (PF). $\times 87,000$
Fig. 15. A mature gap junction in the duodenal epithelium of a 21 day old chick embryo. A dark spot is seen in the center of each particle in the junction. $\times 157,000$ 


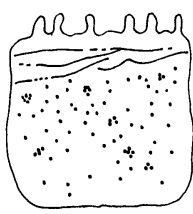

a

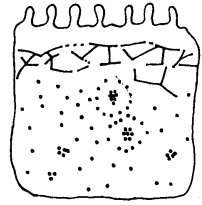

b

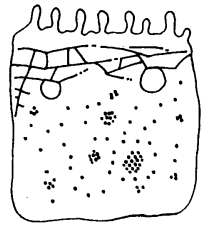

6

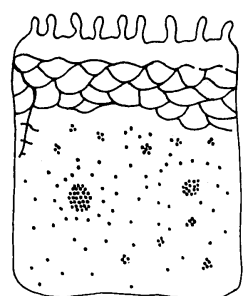

d

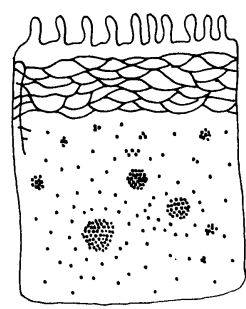

Fig. 16. Schematic representation of the development of the tight junction and gap junction in the duodenal epithelium of the chick embryo. a. 6 day old. b. 9 day old. c. 12 day old. d. 15 day old. e. 18-21 day old.

served in mouse Sertoli cells (NAGANo and SuzukI, 1976) and in spinal ganglia of the chick embryo (PANNESE et al., 1977). This phenomenon was not recongnized in the duodenal epithelium of the chick embryo.

A small central pit about $20 \AA$ in diameter is observed on each elementary membrane-particle of the gap junction in the 18 day old embryo. However, these pits are not noticed on the particles of the small aggregates seen in 6-9 day old embryos.

\section{ニワトリ胚子の十二指腸上皮の接着複合体の発達についての フリーズーエッチング像}

\section{岡 本 壽 男と石村和敬}

ニワトリ胚子 十二指腸上皮の接着複合体の発達の推移をおもにフリーズーエッチング像 によって追跡した.

不完全な閉鎖帯は すでに孵卵 $6 \sim 7$ 日の胚子の十二指腸上皮に存在する. 上皮細胞の 外側細胞膜の上端に位置するこの時期の閉鎖帯は $1 \sim 7$ 本の線條からなり，その深さは 平均 $0.2 \mu \mathrm{m}$ である. 各線條は途切れが多く，線條の交叉はほとんどない．この時期の閉 鎖帯は, “very leaky” 型 (CLAUDE と GoodENOUGH の分類) に相当する. しかし，三つ 以上の細胞が接している部分では，線條が上皮細胞の基底側へ向かって深くのびる.

閉鎖帯の下方の $\mathrm{P}$ 面では，3〜10個の膜内粒子が密に集合している像が しばしば観察さ れる。乙の膜内粒子の集合は，周囲を膜内粒子の少ない量に囲まれている．外側細胞膜の $\mathrm{P}$ 面の中程の高さの部位には，暈をもたない $5 \sim 10$ 個の膜内粒子の疎な集合像も観察され 
る.これらの膜内粒子の集合は 最も原始的なギャップ結合と考えられる.

卵学卵 9 日になると，閉鎖帯の線條は互いに交叉する頻度が増加するが，線條そのものの 途切れは $6 〜 7$ 日のものよりも多い。 また交文した線條によって囲まれる面は角ばって いる。孵卵12日にはこれらの線條は不足部分が補われて連続し，走行も波状の滑らかな ものとなる。志た線條は平均 5.3 本に増加し，深さも平均 $0.3 \mu \mathrm{m}$ と深くなる.

ギャップ結合を形成する膜内粒子は増加を続け，綧卵 9 日では多角形の集合体を示すよ うになる．9〜15日には種々の段階のギャップ結合を見ることができる.

その後も閉鎖帯は発達を続けるが，18日以後には著名な変化を示さない. 孵卵18日には 線條数は 平均 7.2 本, 深さは 平均 $0.4 \mu \mathrm{m}$ を示す。この值は “intermediate to tight” な いし“very tight”の閉領帯に相当する.

この頃にはギャップ結合もその径を増して，直径 $0.3 \sim 0.4 \mu \mathrm{m}$ のものが多くなってく る.またギャップ結合を形成する膜内粒子の中央には。直径約 $20 \AA$ の小孔が観察される. これらの全過程を通じて。ギャップ結合と閉鎖帯が接触することは決してなく，閉鎖帯 とギャップ結合は各々独立して発達する.

\section{References}

Albertini, D. F. and E. Anderson : The appearance and structure of intercellular connections during the ontogeny of the rabbit ovarian follicle with particular reference to gap junctions. J. Cell Biol. 63: 234-250 (1974).

Chalcroft, J. P. and S. Bullivant: An interpretation of liver cell membrane and junction structure based on observation of freeze-fracture replicas of both sides of the fracture. J. Cell Biol. 47: 49-60 (1970).

Claude, P. and D. A. Goodenough : Fracture faces of zonulae occludentes from "tight" and "leaky" epithelia. J. Cell Biol. 58: 390-400 (1973).

Decker, R. S.: Hormonal regulation of gap junction differentiation. J. Cell Biol. 69: 669-685 (1976).

Decker, R. S. and D. S. Friend: Assembly of gap junctions during amphibian neurulations. J. Cell Biol. 62: 32-47 (1974).

Dermietzel, R., K. Meller, W. Tetzlaff and M. Waelsch : In vivo and in vitro formation of the junctional complex in choroid epithelium. A freeze-etching study. Cell Tiss. Res. 181: 427-441 (1977).

Farquhar, M. G. and G. E. Palade : Junctional complexes in various epithelia. J. Cell Biol. 17: 375-412 (1963).

Friend, D. S. and N. B. Gilula : Variations in tight and gap junctions in mammalian tissues. J. Cell Biol. 53: 758-776 (1972).

Fujisawa, H., H. Morioka, K. Watanabe and H. Nakamura : A decay of gap junctions in association with cell differetiation of neural retina in chick embryonic development. J. Cell Sci. 22: 585-596 (1976).

Gilula, N. B., O. R. Reeves and A. Steinbach : Metabolic coupling, ionic coupling and cell contacts. Nature 235: 262-265 (1972).

Goodenough, D. A. and J. P. Revel: A fine structural analysis of intercellular junctions in the mouse liver. J. Cell Biol. 45: 272-290 (1970).

Humbert, F., R. Montesano, A. Perrelet and L. Orci : Junctions in developing human and rat kidney: A freeze-fracture study. J. Ultrastr. Res. 56: 202-214 (1976). 
Johnson, R., M. Hammer, J. Sheridan and J-P. Revel : Gap junction formation between reaggregated Novikoff hepatoma cells. Proc. Nat. Acad. Sci. USA 71: 4536-4540 (1974).

Kreutziger, G. O : Freeze-etching of intercellular junctions of mouse liver. Proc. 26th Electron Microsc. Soc. Amer. 234-235 (1968).

McNutt, N. S. and R. S. Weinstein: The ultrastructure of the nexus: A correlated thinsection and freeze-cleave study. J. Cell Biol. 47: 666-688 (1970).

Montesano, R., D. S. Friend, A. Perrelet and L. Orci : In vivo assembly of tight junctions in fetal rat liver. J. Cell Biol. 67: 310-319 (1975).

Nagano, T. and F. Suzuki : The postnatal development of the junctional complexes of the mouse Sertoli cells as revealed by freeze-fracture. Anat. Rec. 185: 403-418 (1976).

Pannese, E., L. Luciano, S. Iurato and E. Reale: Intercellular junctions and other membrane specializations in developing ganglia: A freeze-fracture study. J. Ultrastr. Res. 60: 169-180 (1977).

Papas, G. D., Y. Asada and M. V. L. Bennett : Morphological correlates of increased coupling resistance at an electrotonic synapse. J. Cell Biol. 49: 173-188 (1971).

Reese, T. S. and M. J. Karnovsky : Fine structural localization of a blood brain barrier to exogenous peroxidase. J. Cell Biol. 34: 207-217 (1967).

Revel, J. P., A. G. Yee and A. J. Hudspeth: Gap junctions between electronically coupled cells in tissue culture and in brown fat. Proc. Nat. Acad. Sci. USA. 68: 2924-2927 (1971).

Revel, J. P., P. Yip and L. L. Chang: Cell junctions in the early chick embryo-A freeze-etch study. Devel. Biol. 35: 302-317 (1973).

Staehelin, L. A. : Structure and function of intercellular junctions. Int. Rev. Cytol. 39: 191-283 (1974).

Staehelin, L. A., T. M. Mukherjee and A. W. Williams : Freeze-etch appearance of the tight junctions in the epithelium of small and large intestine of mice. Protoplasma 67: 165-184 (1969).

Wade, J. B. and M. J. Karnovsky : The structure of the zonula occludens: A singl fibril model based on freeze-fracture. J. Cell Biol. 60: 168-180 (1974).

岡本壽男

干734 広島市霞 1-2-3

広島大学医学部

第二解剖学教室
Dr. Hisao Oкамото

Department of Anatomy

Hiroshima University School of Medicine

Kasumi 1-2-3, Hiroshima

734 Japan 